Check for updates

Cite this: Chem. Commun., 2020, 56,6838

Received 18th January 2020,

Accepted 5th May 2020

DOI: $10.1039 / \mathrm{d} 0 \mathrm{cc} 00478 \mathrm{~b}$

rsc.li/chemcomm

\section{Fluorescent molecular logic gates based on photoinduced electron transfer (PET) driven by a combination of atomic and biomolecular inputst:}

\author{
Glenn D. Wright, ${ }^{a}$ Chao-Yi Yao, ${ }^{a}$ Thomas S. Moody ${ }^{b}$ and A. Prasanna de Silva ${ }^{a}{ }^{a}$
}

\begin{abstract}
Molecular AND logic gates 1, 3, 5 and 7, which are designed according to principles of photoinduced electron transfer (PET) switching, respond to co-existing Candida antarctica lipase $\mathrm{B}$ and $\mathrm{H}^{+}$(and $\mathrm{Na}^{+}$).
\end{abstract}

Molecular logic-based computation ${ }^{1-4}$ requires gates to process and store information. Besides its ability to operate in biocompatible micrometric spaces, the diversity of information available to molecular logic distinguishes it from its semiconductor cousin which employs voltage information only. For instance, the inputs feeding gates can take the form of physical entities (e.g. light dose, ${ }^{5}$ temperature ${ }^{6}$ ), chemical species (e.g. atomic, ${ }^{1}$ molecular ${ }^{7}$ ) and biochemical species (e.g. nucleotides, ${ }^{8}$ enzymes $\left.{ }^{3}\right)$. However, there are hardly any examples of combined atomic and enzyme inputs in the literature, if at all.

Fluorescent PET switches grew out of the sensing literature. ${ }^{9}$ Although atomic inputs were present from the beginning, ${ }^{10}$ protein inputs were incorporated only recently. ${ }^{11}$ Even these covered only some receptor- and transport-proteins.§ A way to incorporate hydrolase enzymes was described by Ojida et al. ${ }^{12}$ and us. ${ }^{13}$ Here, a fluorescent PET system based on a 'fluorophorespacer-amine' format relied on the upward shift of the amine's $\mathrm{p} K_{\mathrm{a}}$ value by $\sim 2 \mathrm{pH}$ units upon hydrolyzing a neighbouring ester into a carboxylate anion. Now we show how such systems can serve as fluorescent molecular logic gates driven by atomic ions, $\mathrm{H}^{+}$and $\mathrm{Na}^{+}$, and a hydrolase enzyme, Candida antarctica lipase B (CALB).

Logic gate $\mathbf{1 9}$ is synthesized by nucleophilic substitution of 4-bromomethyl-7-methoxycoumarin with sarcosine ethyl ester. $\mathbf{1}$ is a typical fluorescent PET 'off-on' switch of the 'fluorophorespacer-receptor' format ${ }^{8}$ with $\mathrm{H}^{+}$being the input. By itself, the 7-methoxycoumarin fluorophore has no significant interaction with $\mathrm{H}^{+}$in the $\mathrm{pH}$ range of our experiments since it lacks a

\footnotetext{
${ }^{a}$ School of Chemistry and Chemical Engineering, Queen's University, Belfast BT9 5AG, Northern Ireland, UK. E-mail: a.desilva@qub.ac.uk

${ }^{b}$ Almac Sciences, Craigavon BT63 5QD, Northern Ireland, UK

$\dagger$ In honour of Professor Eric Anslyn's 60th Birthday.

\# Electronic supplementary information (ESI) available: Synthesis procedures and characterization details for all compounds. See DOI: $10.1039 / \mathrm{d} 0 \mathrm{cc} 00478 \mathrm{~b}$
}

suitable receptor. ${ }^{14} \mathbf{1}$ 's pH-dependent fluorescence intensity $\left(I_{\mathrm{F}}\right)$ is analysed according to eqn $(1)^{14}$ to give $\mathrm{p} K_{\mathrm{a}}=3.6$. The fluorescence quantum yields are $\Phi_{\mathrm{F}_{\max }}=0.97$ and $\Phi_{\mathrm{F}_{\min }}=0.02$.

$$
\log \left[\left(I_{\mathrm{F}_{\max }}-I_{\mathrm{F}}\right) /\left(I_{\mathrm{F}}-I_{\mathrm{F}_{\min }}\right)\right]=\mathrm{pH}-\mathrm{p} K_{\mathrm{a}}
$$

The hydrolysis product of $\mathbf{1}$, which is $\mathbf{2}$ (shown in Scheme 1 as the carboxylate form owing to the operational $\mathrm{pH}$ range of 6-10 for gate tests), is tested similarly and yields $\mathrm{p} K_{\mathrm{a}}=6.7$. The fluorescence quantum yields of 2 are $\Phi_{\mathrm{F}_{\max }}=0.48$ and $\Phi_{\mathrm{F}_{\min }}=$ 0.01 . The lower $\Phi_{\mathrm{F}_{\max }}$ value of $\mathbf{2}(c f . \mathbf{1})$ is due to the three-atom linker folding the carboxylate unit over the fluorophore ${ }^{15}$ to allow intramolecular interaction in the excited state. ${ }^{16}$ All these parameters for all compounds studied are collected in Table 1.

1 was subjected to an enzyme screen to see which enzyme would hydrolyze 1 most efficiently to 2 at pH 7 (Fig. 1). CALB was found to be the most efficient, which is gratifying since CALB is known ${ }^{17}$ to hydrolyze a variety of esters over a wide $\mathrm{pH}$ range. Additionally, it was found that the hydrolysis reaction could be most conveniently followed by the fluorescence emission signal (Fig. 1). Thus we realize that 1 becomes a 'fluorophorespacer $_{1}$-receptor-spacer ${ }_{2}$-enzyme substrate' system.

The fluorescence spectra of $\mathbf{1}$ at $\mathrm{pH} 6$ and 10 with/without CALB exposure for $30 \mathrm{~min}$ are shown in Fig. 2a. The AND logic response of the fluorescence signal is clear since both $\mathrm{H}^{+}$and
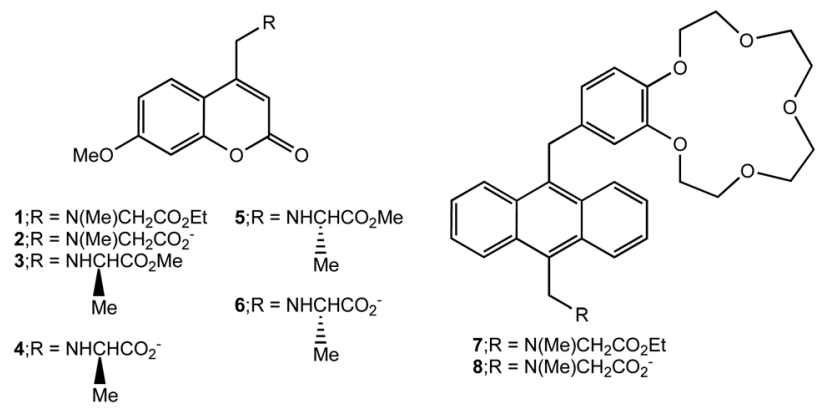

Scheme 1 Structures of logic gates 1, 3, 5 and 7 and their hydrolysis products 2, 4, 6 and 8 respectively. 
Table 1 Parameters obtained for 1-8 via steady-state and timedependent fluorescence spectroscopy ${ }^{a}$

\begin{tabular}{llllll}
\hline Gate & $\mathrm{p} K_{\mathrm{a}}$ & $\Phi_{\max }$ & $\Phi_{\min }$ & $K_{\mathrm{M}}\left(10^{-5} \mathrm{M}\right)$ & $V_{\max }\left(10^{-9} \mathrm{M} \mathrm{s}^{-1}\right)$ \\
\hline $\mathbf{1}$ & 3.6 & 0.97 & 0.02 & 1.9 & 0.50 \\
$\mathbf{2}$ & 6.7 & 0.48 & 0.01 & - & - \\
$\mathbf{3}$ & 4.5 & 0.56 & 0.05 & 1.1 & 7.5 \\
$\mathbf{4}$ & $-{ }^{b}$ & $-{ }^{b}$ & $-{ }^{b}$ & - & - \\
$\mathbf{5}$ & 4.5 & 0.57 & 0.07 & 1.6 & 97 \\
$\mathbf{6}$ & 7.1 & 0.20 & 0.01 & - & - \\
7 & $5.8^{c}$ & $0.18,{ }^{c} 0.16^{d}$ & $0.09^{c}$ & $0.22^{c}$ & $0.75^{c}$ \\
$\mathbf{8}$ & $8.8^{c}$ & $0.15,{ }^{c} 0.12^{d}$ & $0.06^{c}$ & - & -
\end{tabular}

${ }^{a}$ In water: methanol $(4: 1, \mathrm{v} / \mathrm{v})$, except for 7 and 8 where water: DMSO $(1: 1, \mathrm{v} / \mathrm{v})$ is used. ${ }^{b}$ Not determined, but all these values are expected to be close to those of $6 .{ }^{c}$ At $1.0 \mathrm{M} \mathrm{Na}^{+} .{ }^{d}$ At $\sim 0.0 \mathrm{M} \mathrm{Na}^{+}$.

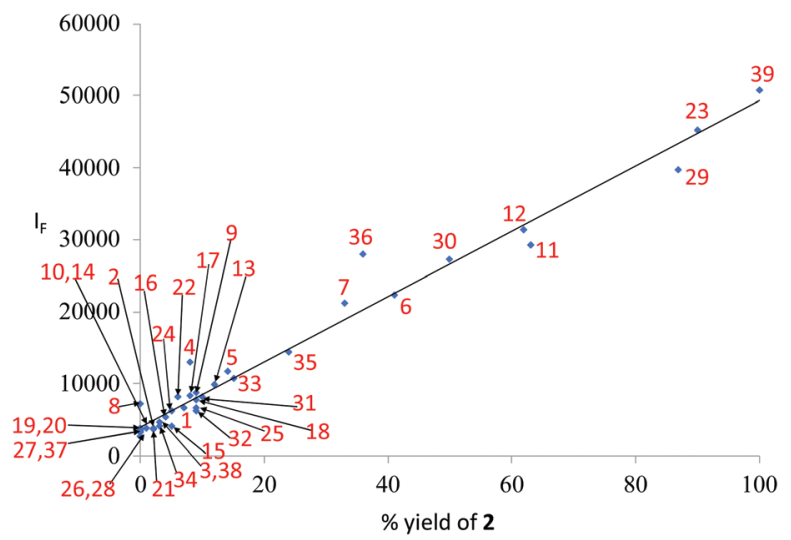

Fig. 1 The influence of various enzymes on the \% yields of the hydrolysis product of $\mathbf{1}$, i.e. $\mathbf{2}$, and their corresponding fluorescence output after exposure for $12 \mathrm{~h}$ at $\mathrm{pH} 7$. Total fluorescence intensity monitoring conducted with $\lambda_{\text {exc }}=$ $326 \mathrm{~nm}$. Enzyme numbers are shown in red. Enzymes: 1. Candida cylindracea lipase C1, 2. Candida cylindracea lipase C2, 3. Rhizopus oryzae lipase, 4. Achromobacter spp. lipase, 5. Alcaligenes spp. lipase, 6. Pseudomonas cepacia lipase, 7. Pseudomonas stutzeri lipase, 8. Rhizopus spp. lipase, 9. Rhizopus niveus lipase, 10. Aspergillus niger lipase, 11. Alcaligenes spp. lipase, 12. Pseudomonas cepacia lipase P2, 13. Mucor javanicus lipase, 14. Penicillium camambertii lipase, 15. Rhizopus oryzae lipase, 16. Rhizopus niveus protease, 17. Bacillus stearothermophilus protease, 18. Aspergillus oryzae protease, 19. Aspergillus melleus protease, 20. Bacillus subtilis protease, 21. Aspergillus spp. aminoacylase, 22. Penicillium fluoroscens lipase, 23. Candida antarctica B lipase, 24. Mucor meihei lipase, 25. Candida antarctica A lipase, 26. Fiscus spp. ficin, 27. Bromeliaceae bromelain, 28. Carica papaya papain, 29. Candida antarctica (immob) lipase B, 30. Porcine pancrease, type II, 31. Bacillus lentus protease, 32. Bacillus lentus (immob) protease, 33. Bacillus lincheniformis protease, 34. Bacillus lincheniformis (immob) protease, 35. Porcine pancrease grade II, 36. Pig liver esterase, 37. Penicillin acylase. 38. Alpha amylase. Data point 39 is pure 2.

CALB are needed to elicit a 'high' fluorescence response from 1. When exposed to CALB at pH 6, 1 gradually hydrolyzes to 2 and shows a gradual increase in fluorescence intensity. The 1-CALB interaction is governed by a Michaelis constant $K_{\mathrm{M}}$ of $1.9 \times$ $10^{-5} \mathrm{M}$ and $V_{\max }$ value of $5.0 \times 10^{-10} \mathrm{M} \mathrm{s}^{-1}$. These values are obtained by applying eqn (2) to convert the rate of change of fluorescence intensity into the rate of change of the product 2 concentration, followed by the application of eqn (3). ${ }^{18}$

$$
\begin{gathered}
V=\mathrm{d}(\mathbf{2}) / \mathrm{d} t=\left[\mathrm{d} I_{\mathrm{F}} / \mathrm{d} t\right] \cdot(\mathbf{1})_{t=0} /\left\{\left[\left(\Phi_{\mathrm{F}_{2}} / \Phi_{\mathrm{F}_{1}}\right)-1\right] \cdot I_{\mathrm{F}_{t=0}}\right\} \\
1 / V=\left[\left(K_{\mathrm{M}} / V_{\max }\right) /(\mathbf{1})\right]+1 / V_{\max }
\end{gathered}
$$

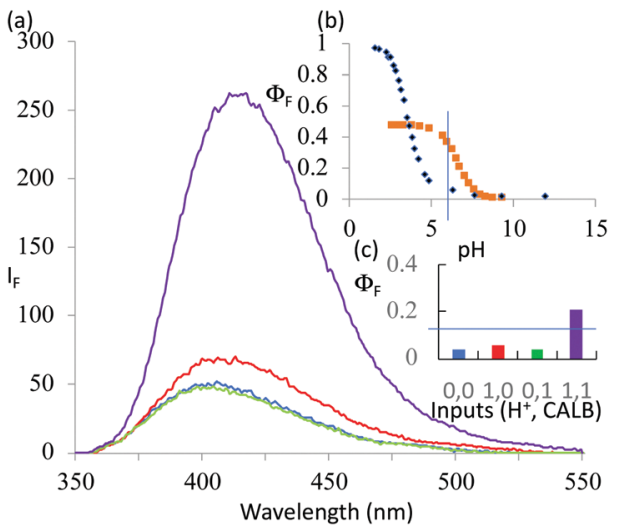

Fig. 2 (a) Fluorescence spectra of $7.3 \times 10^{-6} \mathrm{M} 1$ under stimulation with $\mathrm{H}^{+}$ and CALB inputs for $30 \mathrm{~min}$ in water:methanol $(4: 1, \mathrm{v} / \mathrm{v})\left(\lambda_{\text {exc }}=326 \mathrm{~nm}\right)$ at $20{ }^{\circ} \mathrm{C}$ where 'high' and 'low' $\mathrm{H}^{+}$correspond to $\mathrm{pH} 6$ and 10 respectively and 'high' and 'low' CALB correspond to $7.1 \times 10^{-6} \mathrm{M}$ and $0 \mathrm{M}$ respectively. Input states $\left(\mathrm{H}^{+}, \mathrm{CALB}\right)$ of $(0,0),(1,0),(0,1)$ and $(1,1)$ are shown in blue, red, green and purple respectively. The 'high' level of $\mathrm{H}^{+}$input, $10^{-6} \mathrm{M}$, is chosen from the $\mathrm{pH}$ value at which maximum discrimination of the fluorescence signals between $\mathbf{1}$ and $\mathbf{2}$ is seen in (b). (b) $\Phi_{\mathrm{F}}$ of $\mathbf{1}$ (black) and $\mathbf{2}$ (orange) as a function of $\mathrm{pH}$. (c) Pictorial version of truth table showing $\Phi_{\mathrm{F}}$ values extracted from (a). Output threshold chosen at $\Phi_{\mathrm{F}}=0.13$.

It is to be noted that the enzyme reaction is irreversible under our experimental conditions so that the logic device is suitable only for single-use situations. Such single-use situations are commonly present in the medical diagnostics sphere, as seen with two ${ }^{19}$ - or three ${ }^{20}$ (Scheme 1 ).

Owing to the diversity available in inputs, outputs, power supplies and devices within molecular logic, several routes to reconfigurability have become available. ${ }^{2}$ However, we are not aware of any cases in the primary literature where logic is reconfigured by changing molecular configuration. Since the enantiodiscrimination of enzymes is well-established, we now have an opportunity to present such an approach.

The enantiomeric pair of logic gates $\mathbf{3} \boldsymbol{9}$ and $\mathbf{5} \mathbf{9}$ arise from a synthesis analogous to that of $\mathbf{1}$. The hydrolysis products of these are 4 and $\mathbf{6}$ respectively, although only $\mathbf{6}$ was available for $\mathrm{p} K_{\mathrm{a}}$ determination. $\mathrm{p} K_{\mathrm{a}}$ values are measured for these compounds with the aid of eqn (1), as done for 1 and 2 . The values obtained for 3,5 and 6 are $4.5,4.5$ and 7.1 respectively. The $\mathrm{p} K_{\mathrm{a}}$ value of $\mathbf{4}$ is expected to be the same as that found for its opposite enantiomer 6, i.e. 7.1.

As seen in Fig. 3a, the fluorescence spectra of 3 at pH 6 and 10 with/without CALB exposure for $30 \mathrm{~min}$ correspond to a PASS 0 logic action. On the other hand, Fig. 3b shows an AND logic action for 5. 3 and $\mathbf{5}$ differ in the configuration of the functional groups around the asymmetric carbon. Thus, logic reconfiguring is achieved by changing the molecular configuration of the device. At $\mathrm{pH} 6, K_{\mathrm{M}}$ values are not very different, i.e. $1.1 \times 10^{-5}$ and $1.6 \times 10^{-5} \mathrm{M}$, for 3 and 5 respectively. However, $V_{\max }$ values differ significantly, i.e. $7.5 \times 10^{-9}$ and $9.7 \times 10^{-8} \mathrm{M} \mathrm{s}^{-1}$, as a result of CALB's enantioselectivity.

We have explored the modularity of our design by building a prototype 3-input AND gate 7ब of the 'receptor ${ }_{1}-$ spacer $_{1}$ -

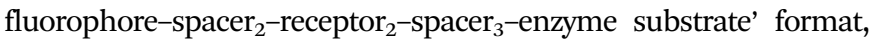



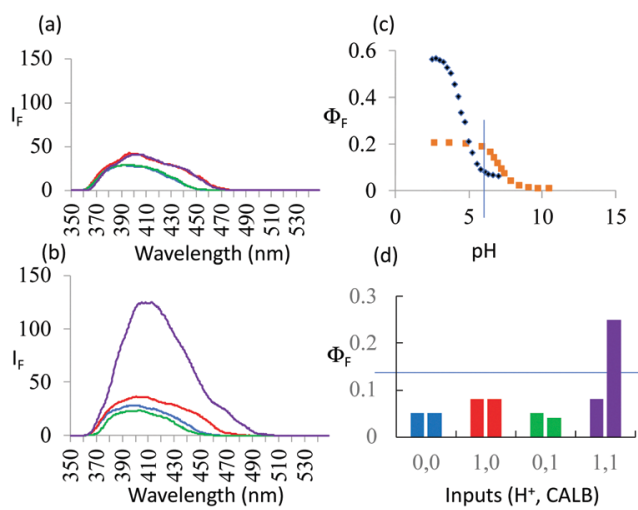

Fig. 3 (a) Fluorescence spectra of $7.3 \times 10^{-6} \mathrm{M} 3$ under stimulation with $\mathrm{H}^{+}$and CALB inputs for $30 \mathrm{~min}$ in water: methanol $(4: 1, \mathrm{v} / \mathrm{v})\left(\lambda_{\text {exc }}=\right.$ $326 \mathrm{~nm}$ ). 'High' and 'low' input levels are as in Fig. 2. Input states are coloured as in Fig. 2. The 'high' level of $\mathrm{H}^{+}$input, $10^{-6} \mathrm{M}$, is chosen from the $\mathrm{pH}$ value at which maximum discrimination of the fluorescence signals between $\mathbf{5}$ and $\mathbf{6}$ is seen in (c). (b) Same as in (a) but for $\mathbf{5}$ instead of 3. (c) $\Phi_{\mathrm{F}}$ of $\mathbf{5}$ (black) and $\mathbf{6}$ (orange)as a function of $\mathrm{pH}$. (d) Pictorial version of truth table showing $\Phi_{\mathrm{F}}$ values extracted from (a) and (b). Left-hand bars of each pair correspond to $\mathbf{3}$ whereas right-hand bars correspond to $\mathbf{5}$. Output threshold chosen at $\Phi_{\mathrm{F}}=0.13$.

which is driven by CALB, $\mathrm{H}^{+}$and $\mathrm{Na}^{+}$. The sensitivity of logic gate 7 's fluorescence to $\mathrm{Na}^{+}, c f$. that of $\mathbf{1}$, arises from the new benzo-18crown-6 ether functional group within 7.

7 is synthesized by reacting a known anthracene-crown ether conjugate $^{21}$ with sarcosine ethyl ester. Its AND logic behaviour is shown in Fig. $4 \mathrm{a}$ and c. Its $\mathrm{p} K_{\mathrm{a}}=5.8$ (at $1.0 \mathrm{M} \mathrm{Na}^{+}$) in water: $\operatorname{DMSO}(1: 1, \mathrm{v} / \mathrm{v}) .8$, the hydrolysis product of 7 , has $\mathrm{p} K_{\mathrm{a}}=8.8$ under the same conditions. The $\log \beta_{\mathrm{Na}^{+}}$values for $\mathbf{7}$ and $\mathbf{8}$ are 0.7 and 0.8 respectively (at $\mathrm{pH} 4.5$ ). The 7-CALB interaction is

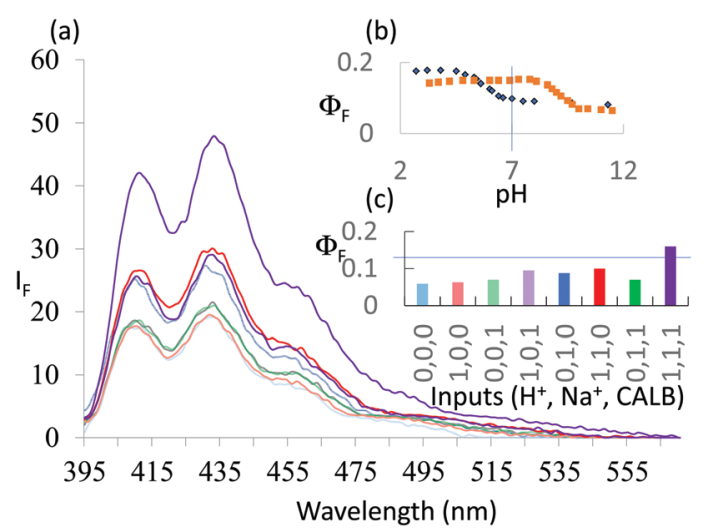

Fig. 4 (a) Fluorescence spectra of $7.3 \times 10^{-6} \mathrm{M} 7$ under stimulation with $\mathrm{H}^{+}, \mathrm{Na}^{+}$and CALB inputs for $30 \mathrm{~min}$ in water: DMSO $(1: 1, \mathrm{v} / \mathrm{v})\left(\lambda_{\text {exc }}=\right.$ $378 \mathrm{~nm}$ ). 'High' and 'low' input levels for $\mathrm{H}^{+}$and CALB are as in Fig. 2, except that 'high' $\mathrm{H}^{+}$is $10^{-7} \mathrm{M}$, with 'high' and 'low' $\mathrm{Na}^{+}$levels being chosen as 1.0 and $0 \mathrm{M}$ respectively. Input states are coloured as in Fig. 1 for 'high' $\mathrm{Na}^{+}$, while those with 'low' $\mathrm{Na}^{+}$are shown in the same colours but with $50 \%$ transparency. The 'high' level of $\mathrm{H}^{+}$input, $10^{-7} \mathrm{M}$, is chosen from the $\mathrm{pH}$ value at which maximum discrimination of the fluorescence signals between $\mathbf{7}$ and $\mathbf{8}$ is seen in (b). (b) $\Phi_{\mathrm{F}}$ of $\mathbf{7}$ (black) and $\mathbf{8}$ (orange) as a function of $\mathrm{pH}$ in the presence of $1.0 \mathrm{M} \mathrm{Na}^{+}$. (c) Pictorial version of truth table showing $\Phi_{\mathrm{F}}$ values extracted from (a). Output threshold chosen at $\Phi_{\mathrm{F}}=0.13$. characterized at $\mathrm{pH} 7$ and at $1.0 \mathrm{M} \mathrm{Na}^{+}$by $K_{\mathrm{M}}=2.2 \times 10^{-6} \mathrm{M}$ and $V_{\max }=7.5 \times 10^{-10} \mathrm{M} \mathrm{s}^{-1}$. This proof of principle study does not examine selectivity issues with respect to other metal ions.

We conclude that the fluorescent PET sensing/switching design is a useful starting point for constructing tailored molecular logic systems which employ mixed inputs from the chemical and biological spheres, especially when the latter concerns a hydrolase enzyme. Such systems are unique when compared with previously developed AND and other logic gates. ${ }^{2,3}$ This approach also allows demonstration of logic reconfiguring by changing the molecular configuration of the logic device.

We acknowledge the Department of Employment and Learning, Northern Ireland and T. J. Lively for support and help.

Note added in proof: Fluorescent PET probes for some oxidoreductase proteins are also available. $\S^{22}$

\section{Conflicts of interest}

There are no conflicts to declare.

\section{Notes and references}

$\S$ See note added in proof.

甲 $1 ;{ }^{1} \mathrm{H} \mathrm{NMR}\left(\mathrm{CDCl}_{3}\right): \delta 1.30\left(\mathrm{t}, 3 \mathrm{H}, \mathrm{OCH}_{2} \mathrm{CH}_{3}, J=7 \mathrm{~Hz}\right), 2.44(\mathrm{~s}, 3 \mathrm{H}$, $\left.\mathrm{NCH}_{3}\right), 3.38\left(\mathrm{~s}, 2 \mathrm{H}, \mathrm{ArCH}_{2} \mathrm{~N}\right), 3.84\left(\mathrm{~s}, 2 \mathrm{H}, \mathrm{NCH}_{2} \mathrm{CO}\right), 3.89$ (s, 3H, OCH $\left.{ }_{3}\right)$, $4.21\left(\mathrm{q}, 2 \mathrm{H}, \mathrm{OCH}_{2} \mathrm{CH}_{3}, J=7 \mathrm{~Hz}\right), 6.35(\mathrm{~s}, 1 \mathrm{H}, \mathrm{CHCO}), 6.83(\mathrm{~m}, 1 \mathrm{H}, \mathrm{ArH})$, $6.87(\mathrm{~m}, 1 \mathrm{H}, \mathrm{Ar} \underline{\mathrm{H}}), 7.90(\mathrm{~d}, 2 \mathrm{H}, \mathrm{ArH}, J=9 \mathrm{~Hz}) .{ }^{13} \mathrm{C} \operatorname{NMR}\left(\mathrm{CDCl}_{3}\right): \delta 41.1$, $41.5,56.8,58.5,100.9,111.8,112.7,112.8,126.8,151.9,156.0,162.2$, 163.7, 172.0. MS(ES): $306.1341\left[\mathrm{M}+\mathrm{H}^{+}\right]$. Calculated $m / z$ for $\mathrm{C}_{16} \mathrm{H}_{20} \mathrm{NO}_{5}{ }^{+}$, 306.1355 .

3; ${ }^{1} \mathrm{H}$ NMR $\left(\mathrm{CDCl}_{3}\right): \delta 1.38\left(\mathrm{~d}, 3 \mathrm{H}, \mathrm{C}\left(\mathrm{CH}_{3}\right) \mathrm{H}, J=7 \mathrm{~Hz}\right), 1.86(\mathrm{~s}, 1 \mathrm{H}$, $\mathrm{NH}), 3.44\left(\mathrm{q}, 1 \mathrm{H}, \mathrm{C}\left(\mathrm{CH}_{3}\right) \underline{\mathrm{H}}, J=7 \mathrm{~Hz}\right), 3.77\left(\mathrm{~s}, 3 \mathrm{H}, \mathrm{CO}_{2} \mathrm{CH}_{3}\right), 3.87(\mathrm{~s}, 3 \mathrm{H}$, $\left.\mathrm{OCH}_{3}\right), 3.89\left(\mathrm{dd}, 2 \mathrm{H}, \mathrm{CH}_{2} \mathrm{NH}, J=16,107 \mathrm{~Hz}\right), 6.43(\mathrm{~s}, 1 \mathrm{H}, \mathrm{CHCO}), 6.82$ $(\mathrm{m}, 1 \mathrm{H}, \mathrm{Ar} \underline{\mathrm{H}}), 6.86(\mathrm{~m}, 1 \mathrm{H}, \mathrm{Ar} \underline{\mathrm{H}}), 7.58(\mathrm{~d}, 1 \mathrm{H}, \mathrm{Ar} \underline{\underline{H}}, 9 \mathrm{~Hz}) \cdot{ }^{13} \mathrm{C} \mathrm{NMR}$ $\left(\mathrm{CDCl}_{3}\right): \delta 17.4,45.8,50.1,53.8,54.4,99.1,108.5,110.1,110.4,123.2$, 151.6, 153.6, 159.6, 160.7, 174.0. MS(ES): 292.1170 [M + $\left.{ }^{+}\right]$. Calculated $\mathrm{m} / z$ for $\mathrm{C}_{15} \mathrm{H}_{18} \mathrm{NO}_{5}{ }^{+}, 292.1185$

5; ${ }^{1} \mathrm{H}$ NMR $\left(\mathrm{CDCl}_{3}\right): \delta 1.38\left(\mathrm{~d}, 3 \mathrm{H}, \mathrm{C}\left(\mathrm{CH}_{3}\right) \mathrm{H}, J=7 \mathrm{~Hz}\right), 1.86(\mathrm{~s}, 1 \mathrm{H}$, $\mathrm{NH}), 3.44\left(\mathrm{q}, 1 \mathrm{H}, \mathrm{C}\left(\mathrm{CH}_{3}\right) \underline{\mathrm{H}}, J=7 \mathrm{~Hz}\right), 3.77\left(\mathrm{~s}, 3 \mathrm{H}, \mathrm{CO}_{2} \mathrm{CH}_{3}\right), 3.87(\mathrm{~s}, 3 \mathrm{H}$, $\left.\mathrm{OCH}_{3}\right), 3.89$ (dd, $\left.2 \mathrm{H}, \mathrm{CH}_{2} \mathrm{NH}, J=16,107 \mathrm{~Hz}\right), 6.43(\mathrm{~s}, 1 \mathrm{H}, \mathrm{CHCO}), 6.82$ $(\mathrm{m}, 1 \mathrm{H}, \mathrm{ArH}), 6.86(\mathrm{~m}, 1 \mathrm{H}, \mathrm{ArH}), 7.58(\mathrm{~d}, 1 \mathrm{H}, \mathrm{ArH}, 9 \mathrm{~Hz}) \cdot{ }^{13} \mathrm{C}$ NMR $\left(\mathrm{CDCl}_{3}\right): \delta 17.4,45.8,50.1,53.9,54.4,99.1,108.6,110.1,110.4,123.2$, 151.5, 153.7, 159.6, 160.7, 174.0. MS(ES): 292.1182 [M + $\left.\mathrm{H}^{+}\right]$. Calculated $m / z$ for $\mathrm{C}_{15} \mathrm{H}_{18} \mathrm{NO}_{5}{ }^{+}, 292.1185$.

7; ${ }^{1} \mathrm{H}$ NMR $\left(\mathrm{CDCl}_{3}\right): \delta 1.29\left(\mathrm{t}, 3 \mathrm{H}, \mathrm{CH}_{2} \mathrm{CH}_{3}, J=7 \mathrm{~Hz}\right), 2.49(\mathrm{~s}, 3 \mathrm{H}$, $\left.\mathrm{NCH}_{3}\right), 3.43\left(\mathrm{~s}, 2 \mathrm{H}, \mathrm{NCH}_{2}\right), 3.50-3.90\left(\mathrm{~m}, 16 \mathrm{H}, \mathrm{CH}_{2} \mathrm{O}\right), 4.19(\mathrm{q}, 2 \mathrm{H}$, $\left.\mathrm{OCH}_{2} \mathrm{CH}_{3}, J=7 \mathrm{~Hz}\right), 4.73\left(2 \mathrm{H}, \mathrm{s}\right.$, AnthC $\left.\underline{H}_{2} \mathrm{~N}\right), 4.88\left(\mathrm{~s}, 2 \mathrm{H}\right.$, AnthCH $\left.{ }_{2} \mathrm{Ar}\right)$, 6.46-6.57 (3H, m, Ar $\underline{\mathrm{H}}), 7.48$ (m, 4H, Anth $\underline{\mathrm{H}}), 8.19$ (d, 2H, Anth $\underline{\mathrm{H}}$, $J=9 \mathrm{~Hz}), 8.61(\mathrm{~d}, 2 \mathrm{H}$, Anth $\underline{\mathrm{H}}, J=9 \mathrm{~Hz}) .{ }^{13} \mathrm{C} \mathrm{NMR}\left(\mathrm{CDCl}_{3}\right): \delta 14.7,35.0$, $45.1,55.0,60.6,69.4,70.0,70.9,71.4,114.3,114.9,117.4,121.2,122.5$, $124.0,125.8,127.3,129.0,140.9,141.4,171.7 . \mathrm{MS}(\mathrm{ES}): 588.2994$ $\left[\mathrm{M}+\mathrm{H}^{+}\right]$. Calculated $\mathrm{m} / z$ for $\mathrm{C}_{35} \mathrm{H}_{42} \mathrm{NO}_{7}^{+}$, 588.2961.

1 A. P. de Silva, H. Q. N. Gunaratne and C. P. McCoy, Nature, 1993, 364, 42.

2 Molecular and Supramolecular Information Processing, ed. E. Katz, Wiley-VCH, Weinheim, 2012; Biomolecular Information Processing, ed. E. Katz, Wiley-VCH, Weinheim, 2012; K. Szacilowski, Infochemistry, Wiley, Chichester, 2012; A. P. de Silva, Molecular Logic-based Computation, Royal Society of Chemistry, Cambridge, 2013; V. Balzani, A. Credi and M. Venturi, Molecular Devices and Machines, VCH, Weinheim, 2nd edn, 2008; A. P. de Silva, Y. Leydet, C. Lincheneau and N. D. McClenaghan, J. Phys.: Condens. Matter, 2006, 18, S1847; S. Uchiyama and A. P. de Silva, Nat. Nanotechnol., 2007, 2, 399; J. Andreasson and U. Pischel, Chem. Soc. Rev., 2015, 44, 1053; B. Daly, J. Ling, V. A. Silverson and A. P. de Silva, Chem. Commun., 2015, 51, 8403; S. Erbas-Cakmak, S. Kolemen, 
A. C. Sedgwick, T. Gunnlaugsson, T. D. James, J. Y. Yoon and E. U. Akkaya, Chem. Soc. Rev., 2018, 47, 2228; J. Andreasson and U. Pischel, Chem. Soc. Rev., 2018, 47, 2266.

3 E. Katz and V. Privman, Chem. Soc. Rev., 2010, 39, 1835; EnzymeBased Computing Systems, ed. E. Katz, Wiley-VCH, Weinheim, 2019.

4 Recent examples: A. C. Sedgwick, H.-H. Han, J. E. Gardiner, S. D. Bull, X.-P. He and T. D. James, Chem. Sci., 2018, 9, 3672; C.-Y. Yao, J. Ling, L.-Y.-H. Chen and A. P. de Silva, Chem. Sci., 2019, 10, 2272; B. Daly, T. S. Moody, A. J. M. Huxley, C.-Y. Yao, B. Schazmann, A. Alves-Areias, J. F. Malone, H. Q. N. Gunaratne, P. Nockemann and A. P. de Silva, Nat. Commun., 2019, 10, 49; J.-Z. Li, Y.-H. Sun, C.-Y. Wang, Z.-Q. Guo, Y.-J. Shen and W.-H. Zhu, Anal. Chem., 2019, 91, 11946; M. V. Refalo, N. V. Farrugia, A. D. Johnson, S. Klejna, K. Szacilowski and D. C. Magri, J. Mater. Chem. C, 2019, 7, 15225; A. Ghosh, A. Patel and M. Schmittel, J. Am. Chem. Soc., 2019, 141, 18954; A. Fernandez, E. J. Thompson, J. W. Pollard, T. Kitamura and M. Vendrell, Angew. Chem., Int. Ed., 2019, 58, 16894.

5 U. Pischel and J. Andreasson, New J. Chem., 2010, 34, 2701; D. Gust, J. Andreasson, U. Pischel, T. A. Moore and A. L. Moore, Chem. Commun., 2012, 48, 1947.

6 S. Uchiyama, N. Kawai, A. P. de Silva and K. Iwai, J. Am. Chem. Soc., 2004, 126, 3032.

7 M. E. Huston, E. U. Akkaya and A. W. Czarnik, J. Am. Chem. Soc., 1989, 111, 8735; C. R. Cooper and T. D. James, Chem. Commun., 1997, 1419; C. R. Cooper and T. D. James, J. Chem. Soc., Perkin Trans. 1, 2000, 963.

8 A. Saghatelian, N. H. Volcker, K. M. Guckian and M. R. Ghadiri, J. Am. Chem. Soc., 2003, 125, 346; M. N. Stojanovic, D. Stefanovic and S. Rudchenko, Acc. Chem. Res., 2014, 47, 1845; R. Lopez, R. F. Wang and G. Seelig, Nat. Chem., 2018, 10, 746.

9 R. A. Bissell, A. P. de Silva, H. Q. N. Gunaratne, P. L. M. Lynch, G. E. M. Maguire and K. R. A. S. Sandanayake, Chem. Soc. Rev., 1992, 21, 187; A. P. de Silva, H. Q. N. Gunaratne, T. Gunnlaugsson, A. J. M. Huxley, C. P. McCoy, J. T. Rademacher and T. E. Rice, Chem. Rev., 1997, 97, 1515; A. P. de Silva, T. P. Vance, M. E. S. West and G. D. Wright, Org. Biomol. Chem., 2008, 6, 2468; A. P. de Silva, T. S. Moody and G. D. Wright, Analyst, 2009, 134, 2385; W. Zhang, Z. Ma, L. P. Du and M. Y. Li, Analyst, 2014, 139, 2641; B. Daly, J. Ling and A. P. de Silva, Chem. Soc. Rev., 2015, 44, 4203; D. Wu, A. C. Sedgwick, T. Gunnlaugsson, E. U. Akkaya, J. Y. Yoon and T. D. James, Chem. Soc. Rev., 2017, 46, 7105.
10 Y. C. Wang and H. Morawetz, J. Am. Chem. Soc., 1976, 98, 3611; B. K. Selinger, Aust. J. Chem., 1977, 30, 2087; G. S. Beddard, R. S. Davidson and T. D. Whelan, Chem. Phys. Lett., 1978, 56, 54; H. Shizuka, M. Nakamura and T. Morita, J. Phys. Chem., 1979, 83, 2019; H. Shizuka, T. Ogiwara and E. Kimura, J. Phys. Chem., 1985, 89, 4302; J. P. Konopelski, F. KotzybaHibert, J.-M. Lehn, J.-P. Desvergne, F. Fages, A. Castellan and H. BouasLaurent, J. Chem. Soc., Chem. Commun., 1985, 433; A. P. de Silva and R. A. D. D. Rupasinghe, J. Chem. Soc., Chem. Commun., 1985, 1669; G. Grynkiewicz, M. Poenie and R. Y. Tsien, J. Biol. Chem., 1985, 206, 3440; A. P. de Silva and S. A. de Silva, J. Chem. Soc., Chem. Commun., 1986, 1709; M. E. Huston, K. W. Haider and A. W. Czarnik, J. Am. Chem. Soc., 1988, 110, 4460.

11 B. McLaughlin, E. M. Surender, G. D. Wright and A. P. de Silva, Chem. Commun., 2018, 54, 1319.

12 Y. Oshikawa and A. Ojida, Chem. Commun., 2013, 49, 11373.

13 G. D. Wright, PhD thesis, Queen's University Belfast, 2010.

14 A. P. de Silva, H. Q. N. Gunaratne, P. L. M. Lynch, A. L. Patty and G. L. Spence, J. Chem. Soc., Perkin Trans. 2, 1993, 1611.

15 F. Hirayama, J. Chem. Phys., 1965, 42, 3163.

16 J. F. Callan, A. P. de Silva and N. D. McClenaghan, J. Chem. Soc., Chem. Commun., 2004, 2048.

17 E. M. Anderson, M. Karin and O. Kirk, Biocatal. Biotransform., 1998, 16, 181.

18 H. Lineweaver and D. Burk, J. Am. Chem. Soc., 1934, 56, 658.

19 T. Konry and D. R. Walt, J. Am. Chem. Soc., 2009, 131, 13232.

20 D. C. Magri, G. J. Brown, G. D. McClean and A. P. de Silva, J. Am. Chem. Soc., 2006, 128, 4950; G. J. Scerri, J. C. Spiteri, C. J. Mallia and D. C. Magri, Chem. Commun., 2019, 55, 4961.

21 A. P. de Silva, H. Q. N. Gunaratne and C. P. McCoy, J. Am. Chem. Soc., 1997, 119, 7891; S. A. de Silva, B. Amorelli, D. C. Isidor, K. C. Loo, K. E. Crooker and Y. E. Pena, Chem. Commun., 2002, 1360; A. P. de Silva, G. D. McClean and S. Pagliari, Chem. Commun., 2003, 2010; S. Uchiyama, E. Fukatsu, G. D. McClean and A. P. de Silva, Angew. Chem., Int. Ed., 2016, 55, 768.

22 T. Guo, L. Cui, J. N. Shen, W. P. Zhu, Y. F. Xu and X. H. Qian, Chem. Commun., 2013, 49, 10820; D. D. Li, Y. Q. Xu, N. N. Zhou, J. X. Liu, R. Wang, T. Cheng, Y. Tang, W. P. Zhu, Y. F. Xu and X. H. Qian, Dyes Pigm., 2017, 136, 627; L. Yang, J. Y. Niu, R. Sun, Y. J. Xu and J. F. Ge, Sens. Actuators, B, 2018, 259, 299; Z. J. Zhang, T. Lv, B. B. Tao, Z. F. Wen, Y. Q. Xu, H. J. Li, F. Y. Liu and S. G. Sun, Bioorg. Med. Chem., 2020, 28, 115280; X. L. Sha, X. Z. Yang, X. R. Wei, R. Sun, Y. J. Xu and J. F. Ge, Sens. Actuators, B, 2020, 307, 127653. 